\title{
Mechanical and Antibacterial Properties of Paper Coated with Chitosan
}

(Sifat Mekanik dan Antibakteria bagi Kertas yang Disalut dengan Kitosan)

\author{
SARANi ZAKARIA*, ChIn HuA ChIA, WAN HASLINDA WAN AHMAD, HatiKa KaCO, \\ SOON WEI CHOOK \& CHI HOONG CHAN
}

\begin{abstract}
Recent developments have found the viability of chitosan as a new alternative additive in the pulp and paper technology. This study was carried out to investigate the effect of chitosan as a paper coating which were prepared by dissolution in acetic acid solution. The mechanical properties of coated paper were improved significantly compared with non-coated paper. The FT-IR spectra showed peak evolution at $1558 \mathrm{~cm}^{-1}$ for coated paper due to the existence of amine group. Since FT-IR spectra for the coated paper was almost identical to the chitosan spectrum, it is assumed that there is an obvious physical interaction rather than the chemical interaction. The SEM micrographs showed that some of the chitosan has occupied the pores and some of them adhered only on the surface. This may be due to the chemical similarities between cellulose and chitosan which enhanced the strength of fiber matrixes via hydrogen bonding. The antibacterial property of coated paper showed that chitosan in dried form has no significant effect but effective when applied as wet solution.
\end{abstract}

Keywords: Antibacterial; chitosan; mechanical properties; paper coating

\section{ABSTRAK}

Perkembangan terkini menunjukkan kesesuaian kitosan sebagai bahan tambah alternatif baru dalam teknologi pulpa dan kertas. Penyelidikan ini mengkaji kesan penyalutan kitosan ke atas kertas yang dilarutkan dalam asid asetik. Sifat mekanik kertas tersalut meningkat dengan ketara berbanding kertas tidak tersalut. Spektrum FT-IR yang diperoleh menunjukkan perbezaan puncak yang jelas antara kertas bersalut dan tanpa salutan pada panjang gelombang 1558 $\mathrm{cm}^{-1}$ yang mengesahkan kehadiran kumpulan amina. Memandangkan spektrum FT-IR yang diperoleh bagi kertas selepas penyalutan menunjukkan profil yang hampir menyerupai spektrum kitosan, maka interaksi yang berlaku diandaikan lebih kepada interaksi fizikal berbanding interaksi kimia. Mikrograf SEM menunjukkan sebahagian daripada kitosan telah mengisi liang-liang pada serabut kertas di samping sebahagiannya lagi berada di bahagian atas permukaan. Ini kerana penyalutan kertas menggunakan kitosan membantu meningkatkan kekuatan ikatan antara serabut dengan serabut pada kertas melalui ikatan hidrogen. Sifat antibakteria kertas tersalut menunjukkan kitosan dalam keadaan kering tiada kesan jelas tetapi efektif apabila dalam larutan basah.

Kata kunci: Antibakteria; kitosan; salutan kertas; sifat mekanik

\section{INTRODUCTION}

Cellulose, chitin and chitosan are natural polymers, derived from renewable resources which proposed an alternative in response to the economic and depleting problems related to the use of fossil counterparts as raw materials for polymer production. Chitosan, a polymer of 1,4 linked $\beta$-D-glucosamine and $\mathrm{N}$-acetyl glucosamine units, is prepared by deacetylation of chitin. Chitosan as a linear polymer of 2-amino-2-deoxy- $\beta$-D-glucan, is a deacetylated form of chitin, a naturally occurring cationic biopolymer (Cissé et al. 2012; Liu et al. 2012). The polymer is formed after the completion of deacetylation process. Chitosan can be considered as a cellulose derivative since the only difference is the group attached to the $\mathrm{C} 2$ atom. In this position, cellulose has a hydroxyl group, whereas chitosan has an amino group while chitin, an acetoamido group. The ratio of acetoamido group to amino groups in the chain is important and is called the degree of deacetylation. The term chitosan is used when deacetylation exceeds $50 \%$ and become soluble in aqueous acidic media (Kuusipalo et al. 2005).

In particular, chitosan has attracted substantial attention in recent years, because of its amazing properties, which make it particularly suited in various applications such as biomedical aids, packaging materials and microcapsules for diverse end use. Other applications of chitosan include; flocculating agent, clarifier, thickener, gas selective membrane, coating material, promoter of plant diseases resistance, wound-healing factor agent and antimicrobial agent. Chitosan can be used as a papermaking additive or as a surface coating. It has been previously investigated and shown that chitosan coating can form strong thin films that could be successfully applied by depositing them onto paper surfaces. It has attracted considerable interest due to its properties which improves the performance of the ensuing coated materials, in terms 
of mechanical, gas-barrier and antimicrobial properties (Cissé et al. 2012). Chitosan in combination with cellulose increases the mechanical strength of paperboard, has antielectrostatic effects on cloth and promotes the dyeability of paperboard. Adding chitosan smoothen the surface, increased the printability properties of paper and modified the fiber properties (Cissé et al. 2012). These materials bond well to the fiber surfaces and are capable of bridging inter-fiber distances, thereby establishing bonds between fibers and fibrils that would not have otherwise formed.

Paper coating technology is a process that has long been used as early as paper-making activities started. The intention of coating is to provide better properties for paper, especially in terms of tensile strength, folding endurance and tear resistance. In addition, the aesthetic values in paper, such as brightness and smoothness could be improved (Ashori et al. 2005).

Polymer type polyelectrolytes had been widely used in papermaking especially as an external size, additives or fillers that can modify the pulp fibre surfaces and solids suspension to be more homogeneous and had a strong attraction between all the components available, especially between the pulp fibres (Ashori et al. 2005). A number of these synthetic additives are non-biodegradable and may cause environmental problems and some pose occupational health and safety risks to paper industry workers. Many of the problems posed by use of synthetic chemical additives may be overcome through the use of biopolymers.

Recent studies on antibacterial activity of chitosan have showed that chitosan is an effective antimicrobial material. The antimicrobial activity of chitosan and chitosan derivatives against both Gram-positive and Gramnegative bacteria is well established. Generally, the effect of chitosan and chitosan derivatives are influenced by a few main factors such as species of bacteria, molecular weight, concentration, viscosity, solvent and environmental factors, such as medium's $\mathrm{pH}$, temperature and ionic strength (Fernandes et al. 2008).

In this study, chitosan is used as a coating materials on A4 printing paper. The aim of this study was to observe the effect of using chitosan solution as coating materials on A4 printing paper. The changes on mechanical and antibacterial properties of paper coated with chitosan will be studied and compared with the uncoated paper. In addition, the potential of the coated paper with chitosan as an antibacterial agent will be highlighted.

\section{MATERIALS AND METHODS}

Chitosan which was supplied by Chito-Chem (M) Sdn. Bhd. was prepared by deacetylation process of chitin processed from giant tiger prawn shell. The chitosan used was labeled as CM60. The printing paper used for coating material was supplied by Goodmate $\mathrm{Sdn}$. Bhd, A4 size (210 $\times 297 \mathrm{~mm}$ ) with a grammage of $80 \mathrm{~g} / \mathrm{m}^{2}$. Glacial acetic acid with the concentration of $99.99 \%$ was purchased from Merck, Germany.

\section{PREPARATION OF CHITOSAN (CH) SOLUTION}

Chitosan concentrations of $2 \%(\mathrm{w} / \mathrm{v})$ acetic acid dissolved in $0.5(\mathrm{v} / \mathrm{v})$ through immersion method. The $\mathrm{CH}$ solution was stirred continuously using mechanical stirrer, 200 $\mathrm{rpm}$ for $24 \mathrm{~h}$ at room temperature $\left(25^{\circ} \mathrm{C}\right)$. Finally, a homogeneous $\mathrm{CH}$ solution was formed.

\section{COATING PROCESS}

Papers were spread with CH coating solution using a bar coater model PI-1210 Film coater. Coatings were made using bar coater at a speed of $4 \mathrm{rpm}$. Each sheet of paper was weighed in advance to obtain the sample weight before coating. Coating was done at room temperature and the samples were dried for $24 \mathrm{~h}$ at room temperature. The samples were reweighed to obtain the weight after coating.

\section{MECHANICAL TESTING OF PAPER}

Few testing have been carried out to test the mechanical properties of A4 size printing paper. Every testing has followed the ISO standard method. Tensile strength test, burst strength test and tearing index test were carried out follow the ISO Standard 1924-2: 1994 (E), ISO Standard 2758: 1983 (E) and ISO Standard 1974: 1990 (E), respectively.

\section{ANTIBACTERIAL TESTING}

Lactobacillus sp. and E.coli were chosen to represent grampositive and gram-negative bacteria in this study. Zone of inhibition method was used to study the antibacterial activity of chitosan coated paper. In order to understand the antibacterial performance of chitosan, two different methods were used, i.e dropping and coating method. For the dropping method, $2 \mathrm{wt} . \%$ of chitosan was prepared by dissolving chitosan in $0.5 \% \mathrm{v} / \mathrm{v}$ of acetic acid. $0.1 \mathrm{~mL}$ of the broth containing $10^{6}$ colony forming unit $\left(10^{6} \mathrm{CFU}\right)$ was inoculated in the nutrient broth. $0.1 \mathrm{~mL}$ of the broth was withdrawn and spread in nutrient agar plate. Sterilized paper disks with $0.6 \mathrm{~mm}$ diameter were placed on the surface of agar and 2 drops of chitosan solution was dripped on the paper disk. In order to compare the antibacterial activity of chitosan, a control sample by using blank paper disk was dripped with 2 drops of $0.5 \% \mathrm{v} / \mathrm{v}$ acetic acid. The plates were incubated at $37^{\circ} \mathrm{C}$ for $24 \mathrm{~h}$. On the other hand, paper that been coated with chitosan was cut into 0.6 $\mathrm{mm}$ diameter. As for comparison, paper disk coated with $0.5 \%$ acetic acid was used as a control sample. The plates were incubated at $37^{\circ} \mathrm{C}$ for $24 \mathrm{~h}$. After the incubation, the plates were taken out and visually observed presents of the inhibition zone for each sample.

\section{CHARACTERIZATION}

\section{FOURIER TRANSFORM INFRARED (FT-IR)}

FT-IR spectra of chitosan, paper and coated paper were recorded using a Perkin Elmer Spectrum 2000 FT-IR 
Spectrometer. Each sample was scanned 16 times in the wavelength range between $4000-550 \mathrm{~cm}^{-1}$ at a resolution of $4 \mathrm{~cm}^{-1}$. These samples were provided in the form of chitosan samples unless provided in powder form.

\section{SCANNING ELECTRON MICROSCOPY (SEM)}

The sample surface morphology was studied using scanning electron microscope (SEM) model XL30 Philips brand. The samples were cut and dried in the oven first to get rid of the moisture content before the scanning was done. The samples were then coated with a layer of gold using SEM coating unit of BIO-RAD Sputter coater ST500 and analyzed at $30 \mathrm{kV}$ operating equipment with $500 \times$ magnification.

\section{RESULTS AND DISCUSSION}

Figure 1 shows the FT-IR spectra for the chitosan, uncoated A4 printing paper, acetic acid treated A4 paper and chitosan coated A4 print paper. The spectra clearly showed the differences between the uncoated and coated paper. Band at $1646 \mathrm{~cm}^{-1}$ was observed in the entire spectrum. This band was due to the vibration of $\mathrm{C}=\mathrm{O}$ which exist in cellulose molecule which overlapped with carbonyl stretch in amides (for chitosan and paper coated with chitosan). However, band at $1555-1558 \mathrm{~cm}^{-1}$ which was only observed in chitosan and paper coated with chitosan samples were due to the vibrating $\mathrm{NH}$ groups in amino groups and stretching vibration of C-N (Lina et al. 2010; Liu et al. 2012). The shifting of the carbonyl band to a lower frequency from 1636 to $1648 \mathrm{~cm}^{-1}$ suggested that these groups were involved in hydrogen bonding with the cellulose functional groups. Therefore there was a decreased in $\mathrm{O}-\mathrm{H}$ and $\mathrm{N}-\mathrm{H}$ vibrational band observed from $3328 \mathrm{~cm}^{-1}$ (uncoated paper) to 3275 $\mathrm{cm}^{-1}$ (chitosan coated paper). This indicates that strong hydrogen bonding interaction between the cellulose and chitosan. However, the vibrational wavelength between the uncoated paper and paper treated with acetic acid has no significant difference. This showed that acetic acid did not contribute in the term of chemical bonding once treated with paper. The spectrum clearly showed that, sample with chitosan coated paper showed similar profile as chitosan with no extra significant peak to show contribution in bonding. This shows that, the interaction that occurs between chitosan and paper lean more towards a physical interaction rather than chemical interactions. Therefore, this shows that chitosan can be exploited as paper additive. If chitosan is used as cationic polyelectrolyte polymer, it can improve bonding between $\mathrm{NH}^{3+}$ charge in chitosan and $\mathrm{OH}^{-}$charge in cellulose paper (Miretzky \& Cirelli 2009).

\section{SURFACE MORPHOLOGY OBSERVATION}

Scanning electron microscope (SEM) was used to observe the morphological surface of paper before and after coating with chitosan. As shown in Figure 2, the A4 printing paper coated with chitosan shows the formation of thick layer on the paper surface. The presence of chitosan thick film causes the formation of dense paper surface. In addition, this observation also showed that paper surface coated with chitosan is non-uniform. The diluted solution penetrates the paper via capillary action and filled the voids while chitosan simultaneously starts covering the fibers. Chitosan was able to coat the cellulose fibers completely by penetrating into the pores of paper and filled the pores of the paper. Therefore, the paper surface was saturated with chitosan (Kuusipalo et al. 2005).

Since chitosan and cellulose have the chemical interaction via hydrogen bonding, this will strengthen bonding between fibers. Paper surface coated with chitosan possess a shining surface. Since the A4 paper is filled with

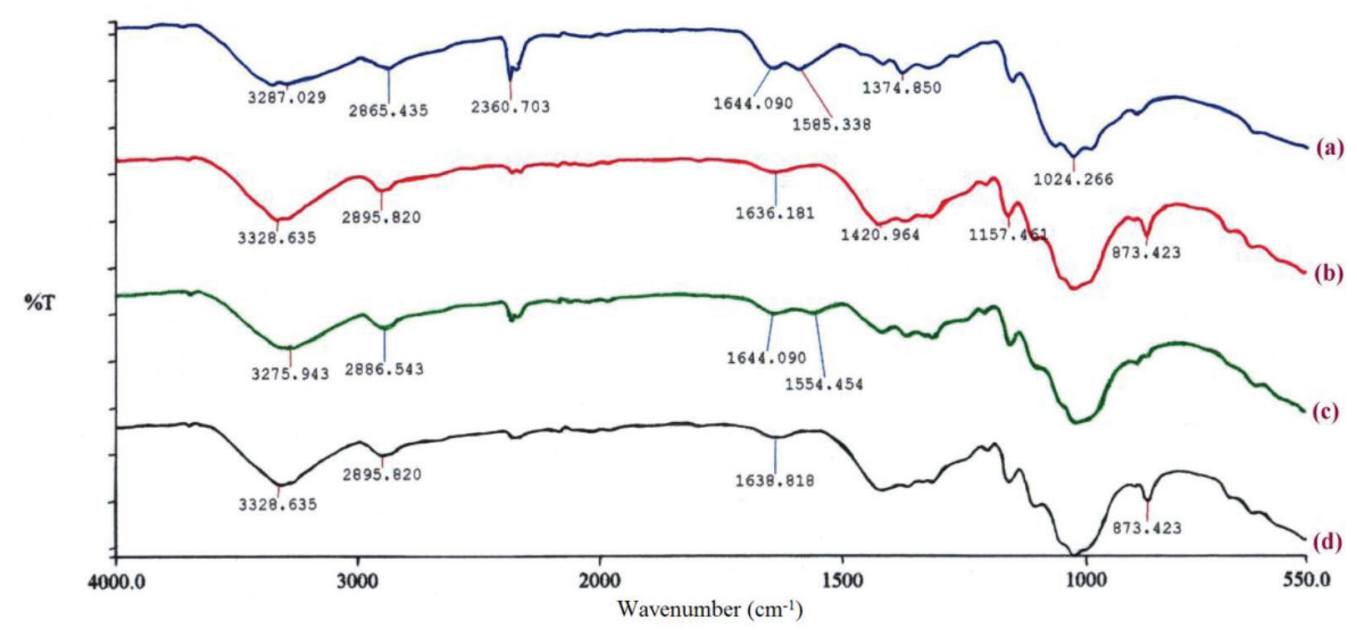

FIGURE 1. FTIR Spectra of (a) chitosan, (b) uncoated A4 printing paper,

(c) coated chitosan and (d) A4 paper treated with acetic acid 

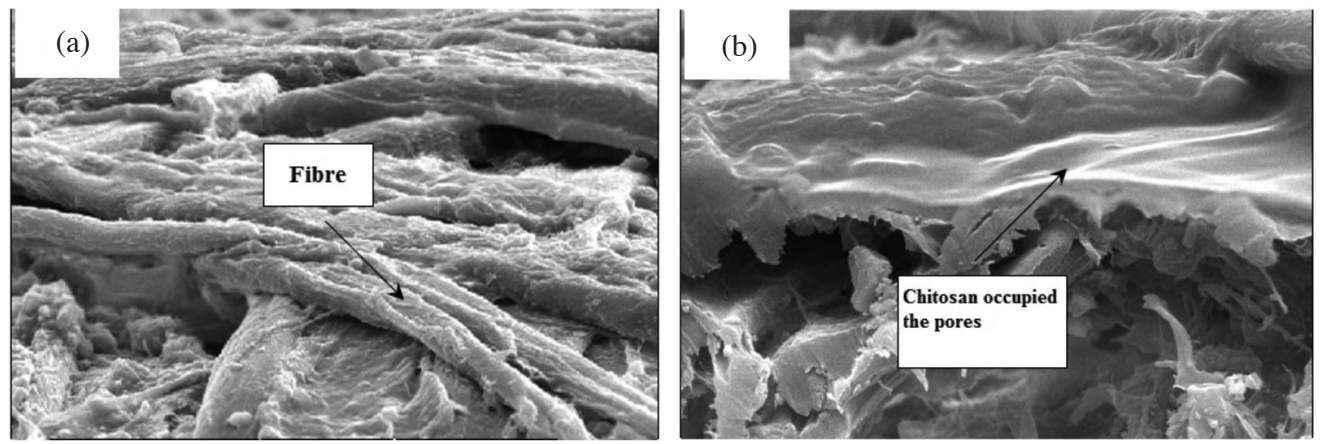

FIGURE 2. SEM micrograph show a comparison of surface morphology in cross sectional cut A4 printing paper (a) before and (b) after coating at 1000× magnification

almost $20 \%$ of $\mathrm{CaCO}_{3}$ as filler, the absorption of chitosan into the fiber via capillary action has been minimized and allows most of chitosan to remain on paper surface (Kuusipalo et al. 2005).

\section{MECHANICAL PROPERTIES OF PAPER}

The used of chitosan as coating material on the paper surface has improved the bond strength between fiber in paper. Therefore, it can be stretched at high elongation rate before break. High tensile strength requires high energy to break the bond. Therefore, a paper with high tensile strength will become more difficult to break when force was applied on it.

Table 1 shows that tensile strength increased for coated paper with chitosan compared with uncoated paper (control paper) and paper treated with acetic acid. Acetic acid has caused reduction in paper strength due to fiber degradation. This was due to the hydrolysis of acid (act as catalyst) in the cellulose chain (cleavage of $\beta$-1-4-glycosidic bond). Hydrogen bonds affect resulting tensile index in which the formation of hydrogen bonds between fiber and water decreased the bond strength in paper. The tensile strength of chitosan coated papers is greater than that of uncoated paper which means that this biopolymer coating agent (Chitosan) has improved the paper strength and ductility. The thick chitosan layer observed on the paper surface could be regarded as a reinforcement layer (Fernandes et al. 2010).

Burst strength is highly related to the strength of fiber bonding in papermaking. The burst strength value for the coated paper has increased by $9 \%$. This was due to the penetration of chitosan into the fibers arrangement and the resemblance of the chemical structure between chitosan and cellulose fibers which has higher compatibility. The presence of acid has weakened the bonding between the fiber and caused fiber degradation. This can be seen by the sample treated with acetic acid where it shows that intrinsic bonding occurred when macromelocule for coating materials adsorbed and improved the bonding with the surface of the substrate (Fernandes et al. 2010).

Tearing resistant depends on both fiber strength and fiber bond. Fiber length is one of the important criteria to characterize paper tearing strength. Tearing resistant increased as bonding degree increased. This was due to the strengthening effect caused by chitosan as bonding formed between fibers was increased (Kuusipalo et al. 2005). Hence, the energy needed to pull out the fiber is higher compared with the energy needed to break the bond. Paper made from longer fiber has higher tearing resistant because work needed to pull out the fiber was higher. From this analysis, the result showed the increment by coated paper. The A4 printing paper increased the tearing resistant by $0.2 \%$. Generally, increment of tearing value requires higher force. Due to the presence of chitosan that increase tearing resistant, higher force also required to tear the samples.

The folding endurance increase with fiber bonding and fiber strength but decrease when bonding between fibre possess stronger bonding. This will cause the paper to be brittle. Paper coated with chitosan has higher folding endurance by $19 \%$ compare with the uncoated paper whereas paper treated with acetic acid shows decreasing on folding endurance by $4.87 \%$.

TABLE 1. Mechanical testing on control paper before and after coating

\begin{tabular}{lccc}
\hline Mechanical testing & $\begin{array}{c}\text { Control paper } \\
\text { (Uncoated paper) }\end{array}$ & $\begin{array}{c}\text { Paper coated with } \\
\text { chitosan }\end{array}$ & $\begin{array}{c}\text { Paper treated with acetic } \\
\text { acid }\end{array}$ \\
\hline Tensile strength $(\mathrm{kN} / \mathrm{m})$ & $6.03 \pm 0.18$ & $6.42 \pm 0.38$ & $5.63 \pm 0.32$ \\
Burst strength $(\mathrm{kPa})$ & $310 \pm 5$ & $348 \pm 18$ & $298 \pm 15$ \\
Tearing resistant $(\mathrm{mN})$ & $522 \pm 26$ & $538 \pm 15$ & $545 \pm 29$ \\
Folding endurance (no.) & $267 \pm 29$ & $318 \pm 34$ & $254 \pm 32$ \\
\hline
\end{tabular}




\section{ANTIBACTERIAL PROPERTIES}

Generally, the dropping method has more obvious zone of inhibition as compared with the coated method. The antibacterial test showed that the presence of inhibition zones surrounding the chitosan coated paper on the plates containing $E$. coli bacteria. In this study, chitosan showed effective antibacterial effect against Gram-negative bacteria (E. coli) compared with Gram-positive bacteria (Lactobacillus sp.). This proves that paper coated with chitosan has the potential for antibacterial purpose because it inhibits the growth of bacteria (Table 2).

\section{DROPPING METHOD}

Table 2 shows the summary of observation on the plate of using dropping method. Figure 3(a) and Figure 3(b) shows the plate of E. coli and Lactobacillus sp. respectively for the sterilized blank paper disk sample and there was no inhibition zone can be observed. Meanwhile, $0.5 \%$ acetic acid bacteria also show no significant effect on the inhibition of both bacteria as shown in Figure 3(c) and Figure 3(d). This has proven that the acetic acid used in this study did not possess any antibacterial properties.

Figure 3(e) and Figure 3(f) shows the presence of inhibition zones at the area where the chitosan was dripped. Chitosan sample shown inhibition effects due to the presence of amine group and the bind water ability of chitosan which cause the dry environment surrounding bacteria and not suitable for bacteria growth. In addition, the ability of water absorption by chitosan from the environment and form the gel exhibit significant antibacterial activity and free amino groups. Besides, the presence of inhibition zone on chitosan coated indicates that the chitosan penetrated into the core of the paper (Bordenave et al. 2010).

\section{COATING METHOD}

The direct effect of chitosan on the bacterial activity can also be seen through the coating method. In this method, the paper was coated with a $2.0 \mathrm{wt}$. $\%$ of chitosan solution and cut into the form of disk with small diameter of $0.6 \mathrm{~mm}$ and placed on the lawn of bacteria that had been spread with bacterial previously. Table 3 shows the result of coated paper prepared by the coating method.

The blank paper showed negative effect which indicates that no inhibition zone can be observed on the E. coli bacteria surface as shown in Figure $3(\mathrm{~g})$. The same result was also observed for paper treated with acetic acid. However, the chitosan coated paper has shown a very small inhibition zone on E. coli bacteria while no inhibition effect was observed on Lactobacillus sp. (the figure was not shown). A previous study reported that chitosan generally showed stronger bacterial effects against Gram-positive bacteria than Gram-negative bacteria (Fernandes et al 2008). However, antibacterial activity also depends on the molecular weight and degree of deacetylation of chitosan. The molecular weight of chitosan used in this study is 161 $\mathrm{g} / \mathrm{mol}$ which are relatively low. Lower molecular weight of chitosan possesses stronger antibacterial activity against gram negative bacteria, stronger compared with Grampositive bacteria.

\section{CONCLUSION}

The FT-IR analysis results indicated that the presence of amine group in chitosan coated paper at wavelength of $1558 \mathrm{~cm}^{-1}$. The FT-IR spectrum clearly showed that, coated paper shows similar profile as chitosan. Micrograph of the surface morphology studies (SEM) showed that chitosan has filled the pores of the paper and partly of. The analysis of the mechanical properties of paper showed an increase in

TABLE 2. Inhibition of bacterial growth used by the droplets of chitosan solution

\begin{tabular}{lcc}
\hline \multirow{2}{*}{ Bacteria } & \multicolumn{3}{c}{ Presence of inhibition zones } \\
& $2 \%$ Chitosan : $0.5 \%$ Acetic Acid & $0.5 \%$ Acetic Acid \\
\hline Escherichia coli & + & + \\
Lactobacillus $\mathrm{sp}$. & - & - \\
\hline
\end{tabular}

A sign with positive indicates positive inhibition effects. A sign with negative indicates negative inhibition effects

TABLE 3. Formation of bacterial growth inhibition zone around the disc of chitosan coated paper after $24 \mathrm{~h}$ at $37^{\circ} \mathrm{C}$

\begin{tabular}{lcc}
\hline Sample & \multicolumn{2}{c}{ Bacteria } \\
& Escherichia coli & Lactobacillus $\mathrm{sp}$. \\
\hline Uncoated paper & - & - \\
Coated paper & + & - \\
Treated paper & - & - \\
\hline
\end{tabular}

A sign with positive indicates positive inhibition effects. A sign with negative indicates negative inhibition effects 

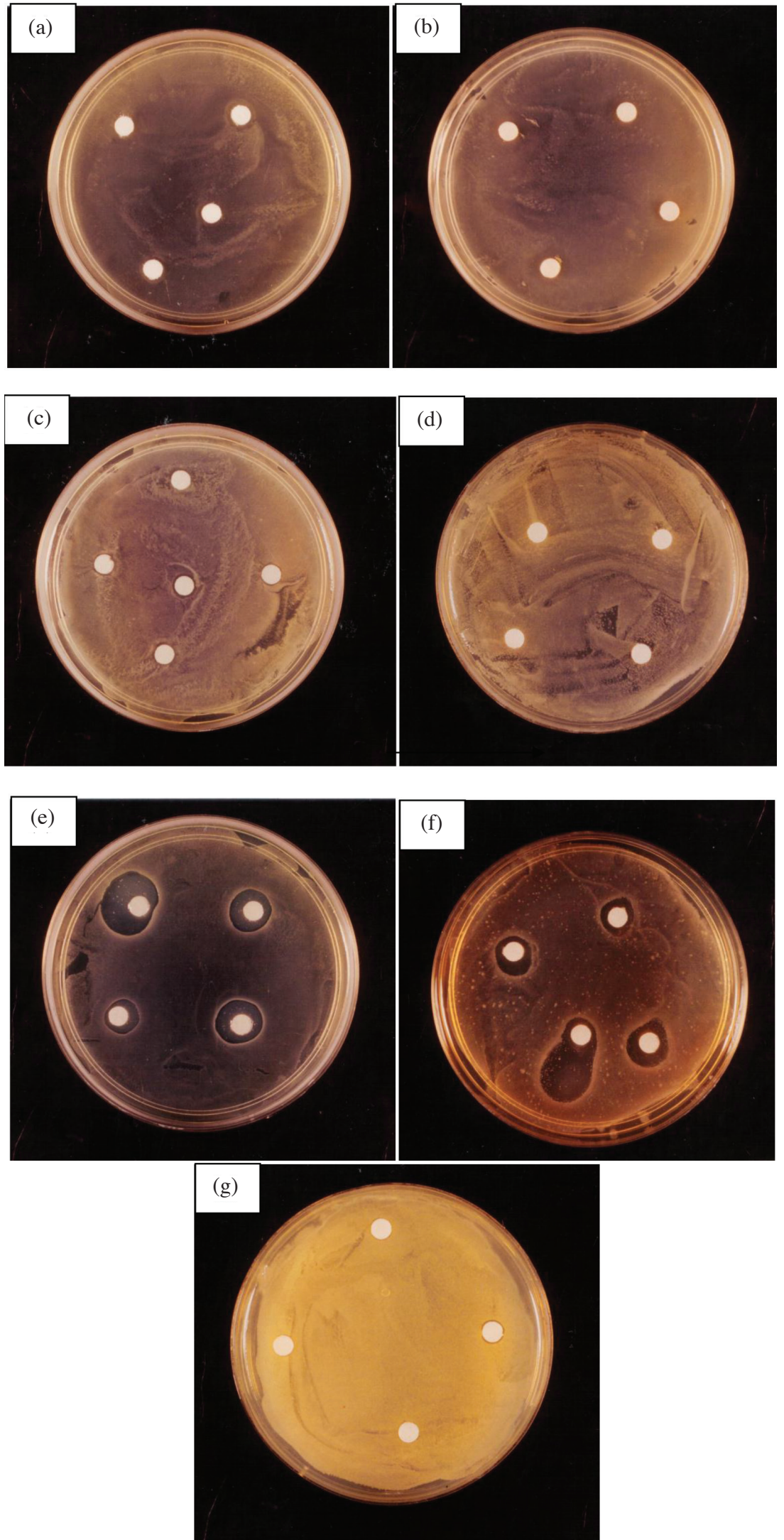

FIGURE 3. The growth of (a) E. coli, (b) Lactobacillus sp. bacteria in the absence of chitosan, the existence of inhibition zones on; (c) E. coli, (d) Lactobacillus sp. lawn using drop method, $0.5 \%$ acetic acid did not inhibit the growth of bacteria; (e) E. coli, (f) Lactobacillus sp. spread and (g) there were no visible of inhibition zones around disk coated with chitosan on lawn bacteria E. coli 
paper strength after coating with chitosan compared with uncoated paper and paper treated with acetic acid.

Generally, chitosan inhibited the growth of bacteria in wet state. Chitosan also showed antibacterial effects against Gram-negative bacteria (E. coli) compared with Gram-positive bacteria (Lactobacillus sp.).Antibacterial testing clearly showed the presence of inhibition zones on the side of chitosan coated paper sample using E. coli droplets spread over the nutrient agar. This proved that the coated paper with chitosan has the potential of antibacterial properties because it prevents the growth of bacteria.

\section{ACKNOWLEDGEMENTS}

The authors wish to thank Universiti Kebangsaan Malaysia (UKM) for the financial support (UKM-DLP-2011-036, UKMGGPM-NBT-085-2010, UKM-GUP-2011-227) and Centre for Research and Instrumentation Management (CRIM) (UKM) for their equipment facility support.

\section{REFERENCES}

Ashori, A., Harun, J., Raverty, W.D.,Zin, W.M. \& Nor, M. 2005. Effect of chitosan addition on the surface properties of kenaf (Hibiscus cannabinus) paper. Iranian Polymer Journal 14(9): 807-814.

Bordenave, N., Grelier, S. \& Coma, V. 2010. Hydrophobization and antimicrobial activity of chitosan and paper-based packaging material. Biomacromolecules 11: 88-96.

Cissé, M., Montet, D., Tapia, M.S., Loiseau, G. \& DucampCollin, M.N. 2012. Influence of temperature and relative humidity on the immobilized lactoperoxidase system in a functional chitosan film. Food Hydrocolloids 28(2): 361-366.

Fernandes, S.C.M., Freire, C.S.R., Silvestre, A.J.D., Desbrie`res, J., Gandini,A.\& Neto, C.P. 2010. Production of coated papers with improved properties by using a water-soluble chitosan derivative. Industrial and Engineering Chemistry Research 49: 6432-6438.
Fernandes, S., Freire, C.S., Pascoal Neto, C. \& Gandini, A. 2008. The bulk oxypropilation of chitin and chitosan and the characterization of the ensuing polyols. Green Chem. 10: 93-97.

Kuusipalo, J., Kaunisto, M., Laine, A. \& Kellomaki, M. 2005. Chitosan as a coating additive in paper and paperboard. TAPPI Journal 4(8): 17-21.

Lina, B., Dua, Y., Li, Y., Liang, X., Wang, X., Deng, W., Wang, X., Li, L. \& Kennedy, J.F. 2010. The effect of moist heat treatment on the characteristic of starch-based composite materials coating with chitosan. Carbohydrate Polymers 81: 554-559.

Liu, Z., Ge, X., Lu, Y., Dong, S., Zhao, Y. \& Zeng, M. 2012. Effects of chitosan molecular weight and degree of deacetylation on the properties of gelatine-based films. Food Hydrocolloids 26(1): 311-317.

Miretzky, P. \& Cirelli, A.F. 2009. Hg(II) removal from water by chitosan and chitosan derivatives: A review. Journal of Hazardous Materials 167(1-3): 10-23.

School of Applied Physics

Faculty of Science \& Technology

Universiti Kebangsaan Malaysia

43600 Bangi, Selangor Darul Ehsan

Malaysia

*Corresponding author; email: szakaria@ukm.edu.my

Received: 16 February 2013

Accepted: 6 March 2015 